\title{
Myth and Postcolonialism in Walcott's Omeros
}

\author{
Gabriel Fajar Sasmita Aji
}

\begin{abstract}
Myth is about hegemony's nostalgia, referring to the past, and postcolonialism is about abolishing hegemony, referring to the future. This strict notion is violated by Walcott's Omeros, the epic of Caribbean postcoloniality. Its term of epic establishes its myth identity, and its postcoloniality emphasizes the future destiny for the Caribbean. How Walcott manipulated the traditional philosophies dealing with the myth is worth discussing due to its postcoloniality endorsing the Caribbean against the European hegemony. The used stigma of the "new world" has been transformed into the postcolonially dignified "New World."

Close reading and postcolonial theories to Omeros, a narrative poem rendering the daily hardships of plain people of the Caribbean shores, are significant to observe Walcott's manipulation in its mythological characters, assumed as being adopted from the old Greek mythology, Odyssey. Omeros's discussion on the past reflects its concern about the future.
\end{abstract}

Index Terms-Caribbean, Greek, mythology, myth, postcoloniality

\section{INTRODUCTION}

Human civilization in fact covers three dimensions: the past, the present, and the future. Each independently functions to stand as its pillars, in which no notion may state that one is more important or significant in comparison with the others. Each has to complete the others together to build a good and ideal structure building of civilization. However, it happens that many discussions tend to merely focus on a special treatment against either one of the dimensions to appear the most important entity while the others are considered the supporting elements. The talk about myth, for instance, would certainly scope the people and time limited to the realm of the past. It means to discuss myth is to address the past only because the present and the future have no portion to take the deal. The story about Grendel and Beowulf, the Trojan war, or the heroes tale is the concrete proof that the readers or audience would create for them the world of the past and rarely involve them in the context of the present days. Indeed, myth is concerned with the people of the past. Even, the definition of myth is often applicable to describe something that is simply not true (Amstrong, 2005). On the other hand, the postcolonial studies put any past deeds as the mere triggers to define or create the possibilities for the future. VS Naipaul's The Enigma of Arrival (1987) clearly points that the future is the main concern which highly adores. Said's Orientalism (1978) has the focus on how to build the future, despite the fact that the future is about the rebirth of the past,

Manuscript received February 16, 2017; revised July 2017. This work was supported in part by the Kohli Center on Intelligent Systems of International Institute of Information Technology, Hyderabad.

Gabriel Fajar Sasmita Aji is with Sanata Dharma University, Indonesia (e-mail: fajar@usd.ac.id). i.e. the ancestry identity. In this context, Said significantly emphasized that for the sake of the future the past should be changed in order not to be controlled by the Western hegemony.

Since each dimension functions as the important and significant pillar, working together with the other two, the human civilization then becomes completely structured. By this perspective, the past is the source of experiences in which humans have undergone trials and errors in order to survive. It then develops into the notion of tradition, which suggests a way of learning against the past. In fact, the term 'civilization' itself emphasizes it by rendering human developments in their survival, from the era of savagery, barbarism, and then civilization, as explained by Tylor (Scarre and Fagan, 2016: 6). Obviously human complexities of civilization continually develop in accordance with human brain and sensitivity in facing the world.

The dimension of "the present" shows the era of the living humans due to the given facilities by 'the past' and to the next survival anticipation for 'the future.' Tradition and myth are simply the instances of facilities from the past. From the tradition humans have learned how to live, and from the myth they come to the awareness of the imagination world. Amstrong (2005) noted it as a faculty to think and to conceive something which is not present and has no objective existence, and put emphasis on the fact myth was in tight accordance with the inability in recording the events during the prehistory. However, the present is also having the duty of preparing and anticipating any attempts of survival for the sake of the future. The campaign of saving the earth is a model how humans also care of the future. The slogan saying that the earth is not the inheritance given by the ancestor but it is the descendant's property is the way of proving that the future belongs the present's responsibility. In this perspective, postcolonialism is an attempt to save the future by comparing it with the past events which should be changed or revised.

The logic of postcolonialism renders the will to avoid the past since it was about the condition of being marginalized and inferiorly dependent. The idea behind it is explained by Ashcroft (2006), as discussion dealing mainly with migration, slavery, resistance, race. Therefore, it is reasonable that the paradigm of postcolonialism is in fact about the future. Even, the past is the realm of fear that had to be avoided and not to be repeated. In other words, postcolonialism has created a gap against the past due to its trauma, and the will to have a new identity different from the past is the only way to oppose the foreign dominance.

However, the genius and brilliant Derek Walcott, from Caribbean, would not be in such the main stream. While a group of postcolonialists held tightly the notion of paradigm of dichotomy, such as either East or West, Black or White, colonized or colonizer, oppressed or oppressor, inferior or 
superior, the past or the future, Walcott has come up to represent the different paradigm. In one hand, the phenomenon of colonialism was historical and the present people can do nothing to change the fact, because it was in the realm of the past. On the other hand, the phenomenon has provided a new opportunity for the ex-colonized to start its different identity and establishment for the sake of the future. Walcott's Omeros is the model how the new paradigm of postcolonialism could accommodate all perspectives dealing what already happened in the past and what would $\&$ should happen in the future due to the newer human civilization.

From the entity of form, Omeros has its specific genre because of its narrative lines. This format seems to give rebirth to the very old form found in the past epics of the old literature. As we know, the genre of epic found its greatness in its narrative lines, and even the significantly famous Greek plays took the form. However, from its entity of content, Omeros discuses the Caribbean postcolonialism, which shows its identity as the up to date topic or idea in the history of human civilization. The thoughts dealing with postcolonialism are about to question the past event of colonialism, which for some historians may be called as the accident of civilization.

\section{DEREK WALCOTT'S OMEROS: FROM MYTH TO EPIC}

Walcott's Omeros is a poem, but it is actually a narrative since it contains many stories ranging from the events in the past to the present and to the hope of the future. From the form, which is in lines, Omeros has totally 7 books containing 64 chapters. Each chapter splits into 3 parts, and every part is about some stanzas of 3 lines. Here is the interesting phenomenon, due to the poem's characteristic, because Omeros is narrating a story but in many lines. This fact actually reminds readers to a genre of epic, from the past, which was commonly in the form of poem containing many and long lines. Adeline Johns-Putra (2006) stated that epic is defined as a long heroic poem, and Frey (1990) suggested that in epic there is conventionally a compilation consisting of tales, myths and histories. Therefore, from its form Omeros is obviously an epic, since it is a long poem which narrates. Meanwhile, from its content the characteristics of epic are shown in the existence of the old figures, such as the character names of Omeros (adapted from Homer), Philoctete, Achille, Hector, and also Helen. This reminds readers to Greek mythology, especially to the old epics of Iliad and Odyssey.

To refer to Ken Dowden and Niall Livingstone (2011: 6), in A Companion to Greek Mythology, the long poem of Omeros may be said to represent again the memory of myth or mythology, which in fact is also a way of maintaining an identity. What identity? It seems the scope belonging the past, in which those heroic characters played dominantly their lives in their world. The greatness of Greek mythology takes role in the establishment of identity for Omeros, since the poem explicitly renders the lives of those past heroes. Though, later readers would find those characters different from the original figures, the existence of those characters is the proof that Omeros actually wants to regain and recall the achievement owned by Iliad and Odyssey as the great epics in Greek mythology. The happenings in "Trojan War" are adopted as the readers follow the conflict between Achille and Hector in competing to have Helen for the lover, the great hero of Philoctete who was prominent in solving the conflict, and many others.

"Ous croire 'ous c'est roi Gros Ilet? Voleur bomme!"

"You think you're king of Gros Ilet, you tin-stealer?'

Then in English: "I go show you who is king! Come!"

Hector came out from the shade. And Achille, the moment he saw him carrying the cutlass, un home fou, a madman eaten with envy, replaced the tin

he had borrowed from Hector's canoe .......

(Omeros, Book I, Ch. III, part I)

Achille had tears in his eyes. He could not hide it. Her elbow moved when Hector climbed in next to her. The van raced the harbor. Achille picked up the fruit.

(Omeros, Book I, Ch. VII, part I)

The above extracts present the conflict between Achille and Hector. The competition of the two emphasizes the competition of being the greater. As in Greek mythology, both Achilles and Hector were the two great heroes of the two opponents. Though, originally the reason of the competition was triggered by the deeds of Paris and Helen, Omeros directly leads the readers into the more significant conflict, i.e. the competition of being greater between Achille and Hector. Here, the poem has no character of Paris, but it has the character of Helen because Omeros focuses on the ultimate conflict between the two heroes, who represent the greatness of each community or society. Perhaps, the poem wants also to reemphasize that the main cause of the past great war between Greece and Troy was merely about woman.

Philoctete tried to make peace between them. He told Hector that they were men, that he bore his own wound as patiently as God allowed him, that the bad blood

between them was worse, that they had a common bond between them: the sea. The sea that changed the cedars into canoes, from the day they had hacked the trees

(Omeros, Book I, Ch. VIII, part III)

Here, Philoctete appears as the man who tried to bridge the conflict between Achille and Hector by stating that they should always remember to have the same bond. In the old mythology the existence of this character is prominent to win the war, and in Omeros he has the role of controlling the two and to stand as the bridge for them.

However, interestingly Omeros in fact presents those great characters in a very specific way totally different from the past epics. In the story those characters appear as the lay persons who are more or less helpless in facing the daily activities of lives. They belong to the society of fishermen or the people of the beach. From the previous quotation, both Achille and Hector are fishermen who should face the daily problems of hardships in order to maintain their lives. That's why the problem of "canoe" is there since this is a kind of a very helpful device for their earning money. If the great heroes could bravely face the natural disturbances, such as high and dangerous waves and also storms, Omeros's Achille and Hector are like the common people in suffering from those natural disasters.

As a matter of fact Omeros is in the realm of the present, and even it is considered the work of postmodernism. Line 
Henriksen (2006) revealed the study on two epic poems: Cantos, by Ezra Pound, and Omeros, by Derek Walcott, and the two are the selected models of epics from the $20^{\text {th }}$ century. The study identified Cantos as the representation of modernism and Omeros as the representation of postmodernism by discussing postcoloniality. Since the era belonging to the Greek mythology is very old, in this perspective Omeros appears to become the agent in establishing the relation of the past with the present and the future. It means there is an attempt of maintaining the past that any processes have been interrelated. Therefore, it may be said that Omeros is a work which enables the readers of the postmodernism era to connect with the myth of the past.

Indeed, in addition to those past characters, there are also some other characters have no relation at all with the past, such as Ma Kilman, Mr Plunkett, and Maud (Plunkett's wife). The way of combining the past characters with the present ones is the strategy of showing that the past is still in the process of the present days, and it means that the past together with the present are preparing for the next process to become the future.

\section{DEREK WALCOTT'S OMEROS:}

\section{POSTCOLONIALISM OF THE CARIBBEAN PEOPLE}

Hamner (1997) identified the work of Omeros, by Derek Walcott, as the "Epic of the Dispossessed," which conveys at least two meanings. The first is about the existence of being epic for Omeros, and the second is the nature of the people shown in its narration. One of the characteristics of being epic is previously mentioned in the above discussion. The existence of the past people, who were great, indicates that Omeros tries to build the historical relationship from the past to the present. The greatness of the names provides the notion that the society was started by the heroes and the essence of the greatness would be eternally maintained in establishing and developing their identity.

However, the facts experienced by those characters, exposed narratively in the poem of Omeros, are the reflection of the past events dealing with the people of Caribbean. As the history noted, the lands of Caribbean started when the European explorers were eager to find "a new world" and they finally built Caribbean as the new world of colonies for them. The events of colonialism by the European countries to many parts of the world, including Caribbean lands, created a new reality concerning with the idea of splitting human beings into the category of being the colonizer and the colonized, being superior and civilized and being inferior and uncivilized. The attribution applied to the Caribbean local people as the dispossessed seems to suggest the broader perspective, because the history wrote that the Caribbean people come from many ethnics, especially from Africa and South Asia.

The start of Caribbean history was the start of the comings of many kinds of people, who were inferior and colonized. The text of Omeros emphasized that the society was firstly compiled of the people displaced from their ancestor (171).

\footnotetext{
In its clicking oarlocks, it idled, my one oar.

But castaways make friends with the sea; living alone

they learn to survive on fistfuls of rainwater and windfall sardines. But a house which is unblest
}

\section{by familiar voices, startled by the clatter}

of cutlery in a sink with absence for its guest, as it drifts, its rooms intact, .........

(Omeros, Book IV, Ch. XXIII, part II)

Their position of being displaced and dispossessed is more emphasized by the description of their reality in their new land. The classical characters live as the local people and they are in their helplessness to deal with difficulties and hardships of life, including the problems of economy and the disastrous natural sea (43-45).

The reality of diaspora and dispossessed is an important factor to build postcoloniality for the Caribbean people. The discussion of Omeros as the epic of dispossessed in the context of the historical life of the Caribbean people is the attempt to have the reflections against the past in order to gain their better future. There are some dealing with the past. The past experience of being colonized is important to undergo reflection because it has provided the stigma of being inferior.

\section{He believed the swelling came from the chained ankles of his grandfathers. Or else why was there no cure? That the cross he carried was not only the anchor's}

but that of his race, for a village black and poor as the pigs that rooted in its burning garbage, then were hooked on the anchors of the abattoir.

(Omeros, Book I, Ch. III, part III)

Colonialism created also the condition of being poor and helpless like the silent pigs which must be ready to slay. By this facts, any attempts to avoid other forms of colonialism are significant to do. Nevertheless, the past also provided the reality that Omeros is the local power. The existence of the classical heroes seems also to suggest that they have inherited from the past the local power dealing with the lives with the sea. Therefore, the Caribbean postcoloniality should start from their own internal power, especially dealing with their close relationship with the natural sea.

However, further there are two dominant aspects in Omeros to present the Caribbean postcoloniality, i.e the aspect of being the dispossessed and the aspect of having various ethnics. The first aspect is dealing with the attempt to become independent and free from being inferior, while the second aspect is about establishing identity by negotiating among many ethnics. The two eventually leads into the Caribbean ideology of the New World, which is the paradigm of hybridity. Stuart Hall (2003: 238) noted that the element of being different was important in establishing hybridity.

\section{CONCLUSION}

Walcott's Omeros stands as the important epic for the Caribbean people, especially in establishing their identity of the new postcolonial society. Different from the conventional or traditional postcolonialism, which emphasizes the binary opposition between East and West, by applying Said's notion in his Orientalism, Caribbean postcolonialism has the new paradigm of being the New World. In one hand it is an attempt of deconstructing the myth of being inferior found in the term of the new world, and on the other hand it is the new postcoloniality. 
Its newness lays at least in two perspectives. One is in its reality of mixing the West and East. The West is represented by the existence of the Greek mythology, which provides the great heroes from the past. Meanwhile, the East is represented by the condition of being inferior and helpless. Second shows in its various ethnics which should negotiate to build their new identity, since they do not have one ancestor. Finally, by this phenomenon Omeros is great in establishing the bridge between myth, which is the realm of the past, and postcolonialism, which is the realm of the present and the past.

\section{ACKNOWLEDGMENT}

Thanks to some friends who convinced me to undergo further myth and postcolonialism. Especially to HISKI, a community of Indonesian scholars in literature, of Sanata Dharma University, which has provided me with the opportunity to discuss Omeros. I guess the next gratitude should be delivered to Sanata Dharma University, who has provided me with the funds for me to attend the Conference in Amsterdam, the Netherlands, to present this paper.

\section{REFERENCES}

[1] Ashcroft, Bill, Gareth Griffiths, dan Helen Tiffin. Empire Writes Back. London: Routledge, 1989.

[2] A. Bill et al., Post-Colonial Studies: The Key Concepts, New York: Routledge, 2000

[3] A. Bill, Post-Colonial Transformation, London \& New York: Routledge, 2001

[4] A. Bill, On Post-Colonial Futures, London \& New York: Continuum, 2001.

[5] B. Edward, Derek Walcott, Cambridge: Cambridge University Press, 2006.

[6] E. M. Berens, The Myths and Legends of Ancient Greece and Rome, Andrews UK Limited, 2010.

[7] B. Elleke, Colonial and Postcolonial Literature, Oxford: Oxford University Press, 1995.

[8] D. Loughrey and M. Elizabeth, Routes and Roots, Honolulu: University of Hawai'i Press, 2007.

[9] D. A. D. S. L. Welsh, The Routledge Reader in Caribbean Literature, London \& New York: Routledge, 1996.

[10] D. Alison, Twentieth-Century Caribbean Literature, London \& New York: Routledge, 2006

[11] E. Terry, Literary Theory, an Introduction, Oxford: Blackwell, 1983.

[12] E. Umberto, The Role of the Reader, London: Hutchinson \& Co. Ltd, 1981.

[13] D. H. Figueredo and D. F. Argote-Freyre, A Brief History of The Caribbean, New York: Facts on File, Inc, 2008.
[14] F. Northrop, Anatomy of Criticism: Four Essays, Princeton: Princeton University Press, 1990.

[15] F. M. Cristina, Agenda: Special Issue on Derek Walcott, London: Agenda and Editions Charitable Trust, 2002-2003.

[16] H. Stefano, Nationalism and Identity: Culture and the Imagination in a Caribbean Diaspora, Kingston: University of the West Indies Press, 2006.

[17] H. D. Robert, Epic of the Dispossessed, Columbia: University of Missouri Press, 1997.

[18] H. Line, Ambition and Anxiety, Ezra Pound's "Cantos" and Derek Walcott's "Omeros" as Twentieth-Century Epics, Amsterdam-New York: Rodopi, 2006.

[19] L. Mikko, Cultural Analysis of Texts, London: Sage Publications Ltd., 2000.

[20] P. Shalini. The Caribbean Postcolonial, New York: Palgrave Macmillan, 2004.

[21] R. H. David, The Critical Tradition, Boston: Bedford Books, 1998.

[22] S. W. Edward, Culture \& Imperialism, London: Vintage, 1993.

[23] S. W. Edward, Orientalism, New York: Vintage Books, 1979.

[24] S. W. Edward, Reflections on Exile, Cambridge: Harvard University Press, 2002.

[25] T. John, Derek Walcot. Manchester: Manchester University Press, 1999.

[26] Torres-Saillant, An Intellectual History of the Caribbean, New York: Palgrave Macmillan, 2006.

[27] W. Derek, What the Twilight Says; Essays, New York: Farrar, Straus \& Giroux, 1998.

[28] W. Derek, Omeros. New York: Farrar, Straus \& Giroux, 1990.

[29] W. Dennis, Postcolonial Nostalgias. New York: Routledge, 2011.

[30] W. Patrick, dan Laura Chrisman, eds. Colonial Discourse and Post-Colonial Theory, New York: Columbia University Press, 1994.

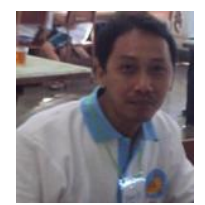

Gabriel Fajar Sasmita Aji, M.H um was born in Yogyakarta, Indonesia, in June 10, 1966. His undergraduate degree was in the study of the English Literature, from Gadjah Mada University (graduated 1994). His master degree was in literature from University of Indonesia in 2003. Meanwhile the doctoral program was also from University of Indonesia, with the similar study in 2014. He specialized in the study of postcolonialism, especially Caribbean Literature. He is also interested in some researches on Cultural Studies 